\title{
Role of cardiac MRI in acute myocardial infarction
}

\author{
Erwin Mulia, Sony H.Wicaksono, Manoefris Kasim \\ Department of Cardiology and Vascular Medicine, Faculty of Medicine,Universitas Indonesia/National Cardiovascular Center Harapan \\ Kita, Jakarta, Indonesia
}

\begin{abstract}
Abstrak
Angka kematian pada pasien dengan infark miokardium akut (IMA) telah menurun secara signifikan oleh karena strategi terapi reperfusi saat ini. Terapi reperfusi dapat berakibat pada cedera reperfusi. Oleh karena itu, tatalaksana pada pasien ini menghadapi tantangan baru dalam hal diagnosis dan tatalaksana gagal jantung, identifikasi kondisi iskemia, estimasi keperluan antikoagulan, dan penilaian risiko kardiovaskular secara menyeluruh. Ilustrasi kasus ini akan menunjukkan pengaruh magnetic resonance imaging (MRI) kardiak dalam penilaian patofisiologi IMA pada era terapi reperfusi. MRI kardiak akan memberikan informasi berguna yang akan membantu para klinisi dalam tatalaksana dan pemilihan strategi terapi spesifik pada pasien IMA. (Med J Indones. 2013;22:46-53)
\end{abstract}

\begin{abstract}
Mortality in patients with acute myocardial infarction (AMI) has decreased significantly and appears to be the result of current reperfusion therapeutic strategies. Reperfusion itself may develop into reperfusion injury. Therefore, management of these patients poses several challenges, such as diagnosing and managing heart failure, identifying persistent or inducible ischaemia, estimating the need for anticoagulation, and assessing overall cardiovascular risk. This case presentation will demonstrate the impact of cardiac magnetic resonance imaging (MRI) in the assessment of the pathophysiology of AMI in the current reperfusion era. Cardiac MRI can provide a wide range of clinically useful information which will help clinicians to manage and choose specific therapeutic strategies for AMI patients. (Med J Indones. 2013;22:46-53)
\end{abstract}

Keywords: Acute myocardial infarction, cardiac magnetic resonance imaging, reperfusion injury

Nowadays, at least $70 \%$ of patients hospitalized with acute myocardial infarction (AMI) survive the acute hospital phase. ${ }^{1}$ Mortality has decreased significantly and appears to be the result of the decline in the incidence of ST-segment elevation myocardial infarction (STEMI) along with the absolute reduction of overall mortality due to the efficacy of current therapeutic strategies either by thrombolitic therapy or primary percutaneous coronary intervention $(\mathrm{PCI})^{2,3}$ Reperfusion itself, after prolonged coronary occlusion may develop into reperfusion injury associated with impairment of microcirculatory flow and possible further deterioration due to intramyocardial haemorrhage. ${ }^{4}$ Therefore, management of these patients poses several challenges, such as diagnosing and managing heart failure, identifying persistent or inducible ischaemia, estimating the need for anticoagulation, and assessing overall cardiovascular risk. Cardiac imaging plays a prominent role in all of these tasks, especially cardiac magnetic resonance imaging (MRI). ${ }^{5}$

The pathological consequences of reperfusion strategies can be currently detected by cardiac MRI. Cardiac MRI can provide a wide range of information such as myocardial oedema (myocardium at risk), location of transmural necrosis, quantification of infarct size (IS) and microvascular obstruction leading also to intramyocardial haemorrage. ${ }^{4}$ Moreover, cardiac MRI provides an accurate and reproducible modality for the assessment of global ventricular volumes and function. ${ }^{6}$

This case presentation will demonstrate the impact of cardiac MRI in the assessment of the pathophysiology of AMI in the current reperfusion era, focusing on clinical applications and future perspectives for therapeutic strategies.

\section{CASE ILLUSTRATION}

Patient 29 years old male came to National Cardiovascular Center Harapan Kita on May, 102012 with extensive anterior STEMI 8 hours onset Killip I. Patient's BMI $17.2 \mathrm{~kg} / \mathrm{m}^{2}$, blood pressure 116/74 $\mathrm{mmHg}$, heart rate $69 \mathrm{bpm}$ with normal physical examination. He was an active smoker.

Electrocardiogram (ECG) revealed sinus rhythm with ST elevation and Q waves at V1-V4, aVL leads (Figure 1). Chest $X$-Ray showed no sign of cardiomegaly and congestion. Patient was given double anti-platelet, nitrates, and eptifibatide. He underwent primary PCI, since the coronary angiography showed thrombus at left anterior descending (LAD) with thrombolysis in myocardial infarction (TIMI) 3 flow (Figure 2), total occlusion at distal diagonal 2 and others within normal limit so primary PCI wasn't performed.

Laboratory results revealed CKMB 337 U/L, troponin T $2.95 \mathrm{ng} / \mathrm{mL}$, total cholesterol $157 \mathrm{mg} / \mathrm{dL}$, 


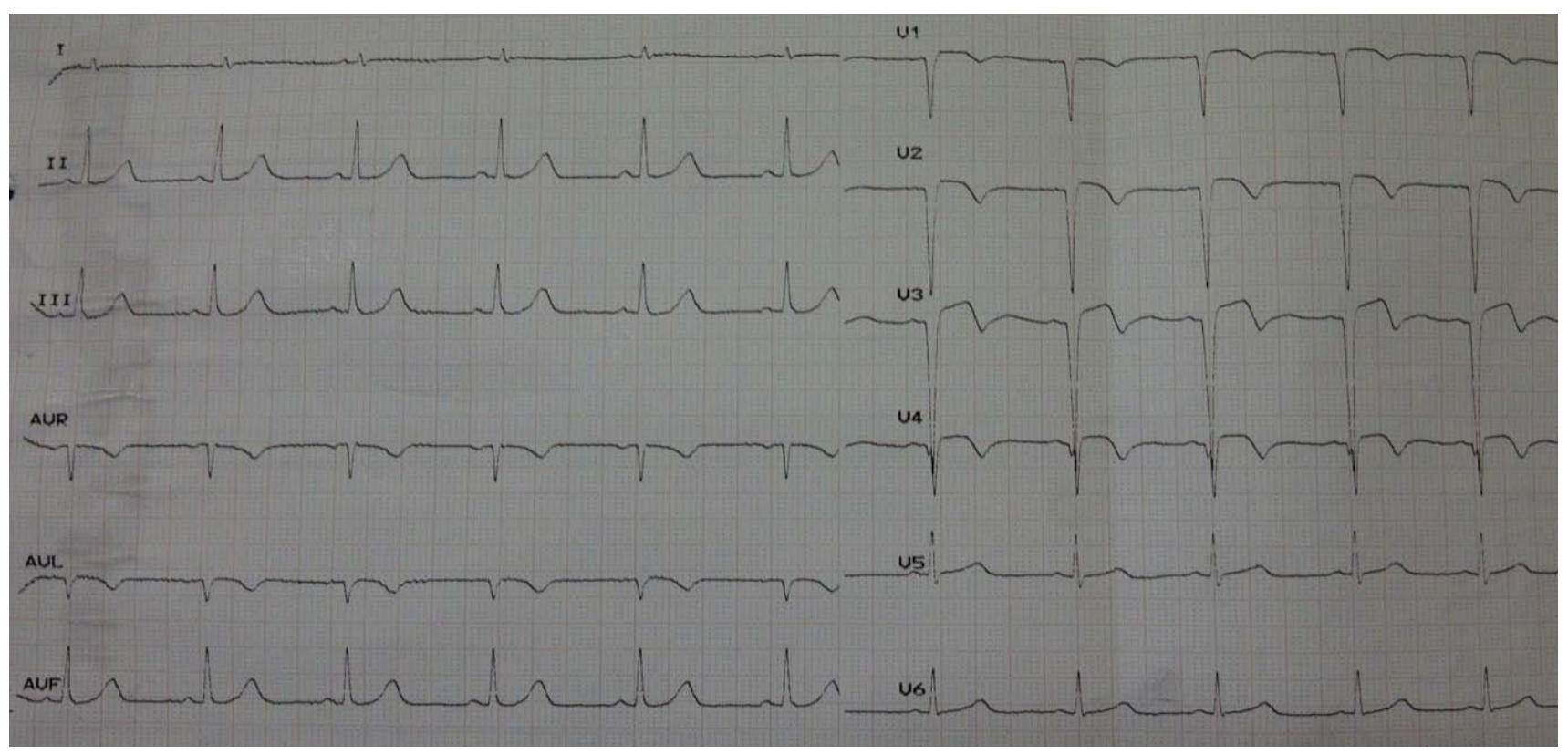

Figure 1. Electrocardiogram (ECG)

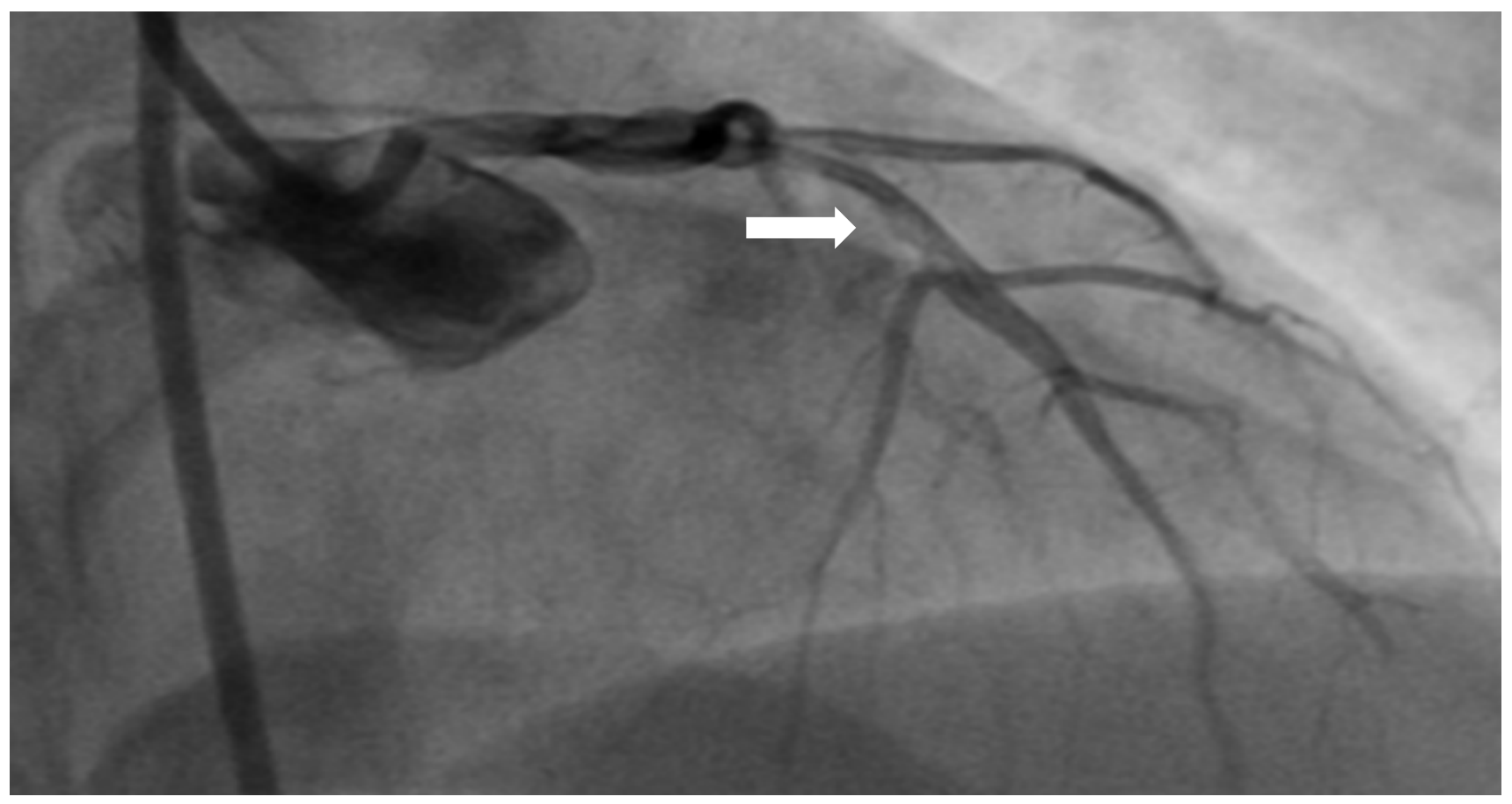

Figure 2. Thrombus at left anterior descending (LAD)

HDL-C 34 mg/dL, LDL-C $102 \mathrm{mg} / \mathrm{dL}$, triglyceride $140 \mathrm{mg} / \mathrm{dL}$, normal glucose tolerance test and kidney function. Echocardiography showed EDD $46 \mathrm{~mm}$, ESD $33 \mathrm{~mm}$, LVEF 39\% (Simpson) and TAPSE $1.9 \mathrm{~cm}$. Further examination by cardiac MRI (Figure 3-5) showed LVEF 48\%, RVEF 55\% with rest subendocardial defect at left anterior descending (LAD) area, intramural haemorrhagic at anterior region, and subendocardium scar formation at LAD area (non viable with LGE $>50 \%$ transmurality). Patient was discharged in stable condition on May, 142012 and was given double anti-platelet, simvastatin, nitrates, carvedilol, and ramipril.

Further evaluation using single photon emission computer tomography (SPECT) (Figure 6) showed partial reversible defect at basal anteroseptal, anterior, apicoseptal, and mid anterolateral. Fixed defect at mid 

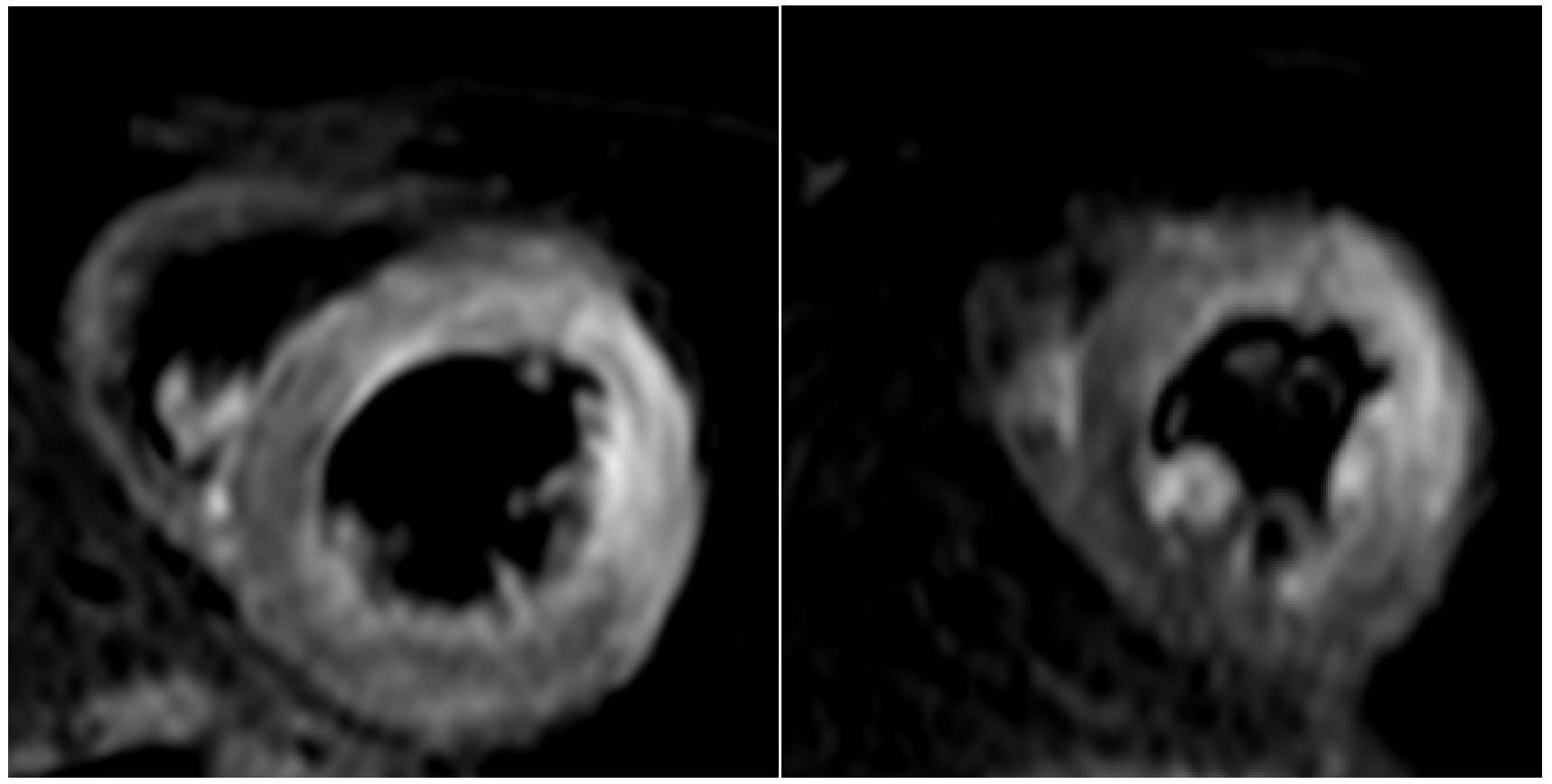

Figure 3. T2-weighted showing myocardial oedema 'myocardium at risk'
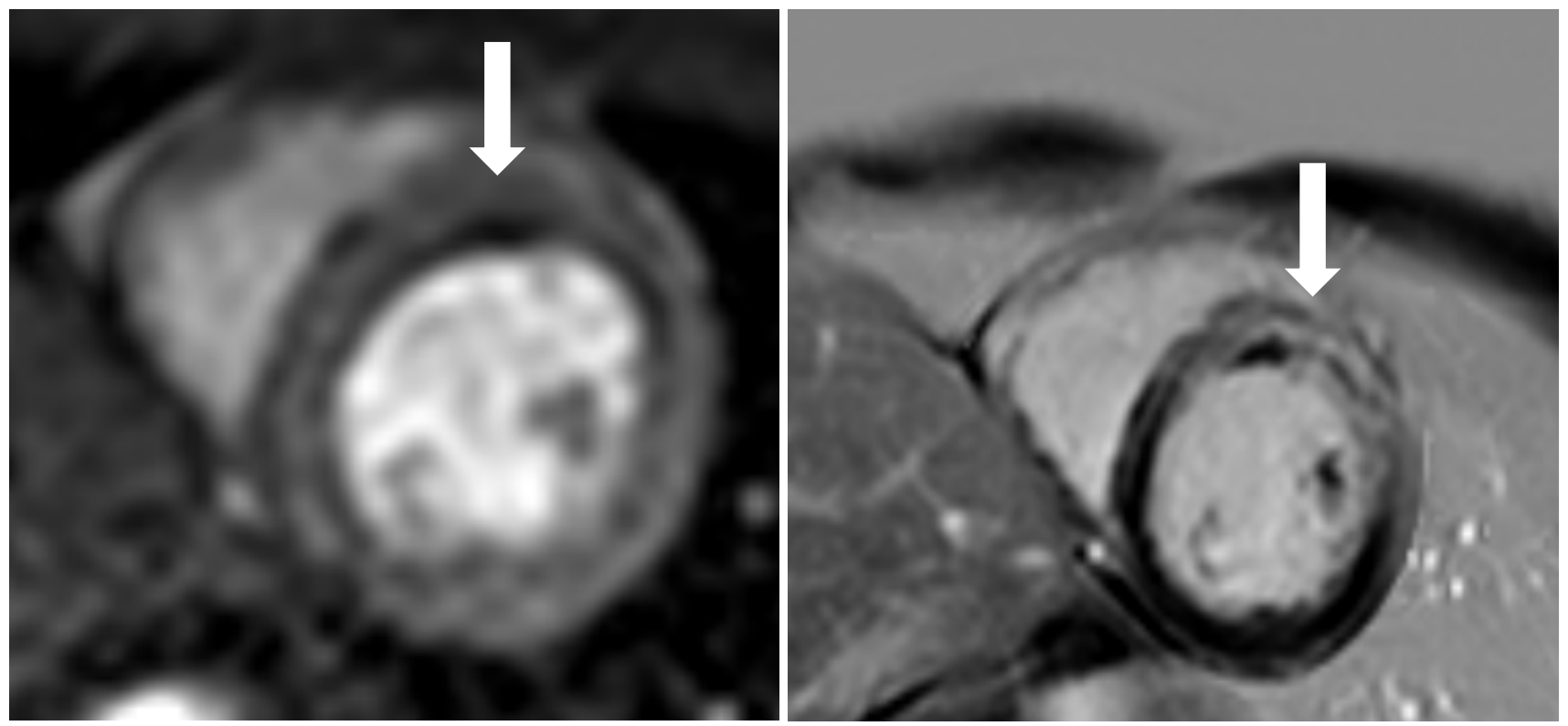

Figure 4. Hypoenhancement in first pass perfussion and positive late gadolinium enhancement (LGE)

anteroseptal, anterior, apex, and apicolateral. Perfussion defect size $40 \%$ at stress and $45 \%$ at rest. Rest LVEF $52 \%$ and stress LVEF $56 \%$.

\section{DISCUSSION}

\section{Myocardial ischemia}

Cardiac MRI provides the assessment of function, perfusion, and tissue characterization in a highly reproducible manner during a single examination even in patients with acoustic window limitations. ${ }^{7}$ Cine MRI for evaluation of cardiac volumes, mass, and systolic function is considered a gold standard compared with other imaging modalities. ${ }^{6}$ The steady-state free precession (SSFP) sequences for cine images have replaced the older turbo gradient echo due to increased natural contrast between blood and endocardial border. ${ }^{8,9}$ Regional myocardial function including wall thickening, evaluation and measures of myocardial strain may also be perfomed. ${ }^{10}$ 


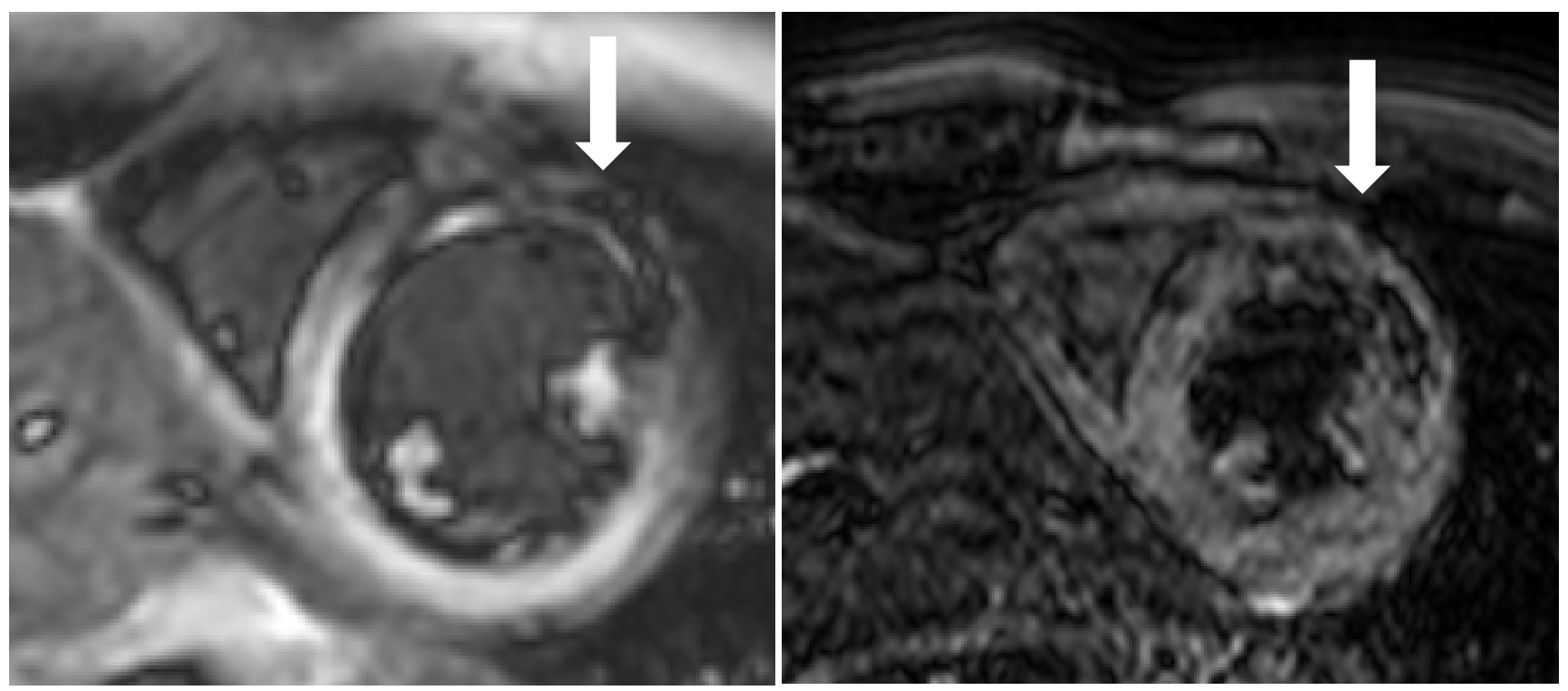

Figure 5. Intramyocardial haemorrhage

Myocardial oedema in the acute phase of myocardial infarction can be visualized as a bright signal on T2weighted images, defining 'myocardium at risk'11 (Figure 3). The major advantages of this technique are to distinguish chronic from acute infarction and to quantify the proportion of myocardial salvaged by comparing $\mathrm{T} 2$-weighted oedematous size and late enhancement images. ${ }^{12,13}$

Late gadolinium enhancement (LGE) images are T1-weighted inversion recovery sequences acquired about $10 \mathrm{~min}$ after intravenous administration of gadolinium. Gadolinium enhances its distribution volume in certain conditions such as necrotic or fibrotic myocardium (hyperenhancement). ${ }^{3}$ The pattern of LGE is useful to differentiate post-infarction necrosis (subendocardial or transmural LGE) from fibrosis in nonischaemic dilated cardiomyopathies (mid-wall LGE, subepicardial LGE), or myocarditis (subepicardial or focal LGE) (Figure 4-right). There was subendocardial LGE in this patient suggested the result of post infarction necrosis. Delayed postcontrast sequences are currently used also to evaluate persistent microvascular dysfunction/damage: in the context of white LGE regions may coexist dark hypoenhanced areas, traditionally referred to as microvascular obstruction (Figure 5)., ${ }^{3,14}$

In early phase of a coronary occlusion, the discrepancy between myocardial oxygen supply and demand lead to myocardial ischaemia and if persists, myocardial injury becomes irreversible and the necrosis extends from the subendocardium towards the subepicardium. ${ }^{15}$ The final IS depends mainly on the extent of the so-called 'risk area', defined as the myocardial area related to an occluded coronary artery with complete absence of blood flow, either antegrade or collateral. Up until now, myocardium at risk has been measured by SPECT using technetium-based tracer. ${ }^{3}$

The most important application of MRI is the evaluation of 'salvaged myocardium'. Friedrich et al have compared T2-weighted images with LGE to visualize reversible and irreversible myocardial injury. ${ }^{13}$ Thereafter, many clinical studies have evaluated the potential of MRI to assess myocardial oedema in comparison with well-established techniques. ${ }^{16-19}$ The concept of reduction of total viable myocardium amount in proportion to the delay on time-to-reperfusion is demonstrated in vivo, the salvaged myocardium (the difference between area of increase T2 signal and area of LGE) is markedly reduced when reperfusion occurs $>90 \mathrm{~min}$ after coronary occlusion in contrast with patients with $\leq 90$ min of delay. ${ }^{20}$ We also discovered the same condition in this patient, since the patient came in 8 hours onset of AMI.

\section{Reperfusion injury}

Reperfusion injury consists of no-reflow phenomenon, microvascular obstruction, and haemorrhage. The assessment of microvascular damage had been performed using MRI first-pass perfusion and the delayed post-contrast sequences. ${ }^{3}$ Currently, it is generally accepted that delayed hypoenhancement is less sensitive than first pass (Figure 4-left) and the persistence of a hypoenhancement on delayed contrast sequences (10-20 min after injection) seems to characterize a persistent microvascular damage. ${ }^{14}$ 


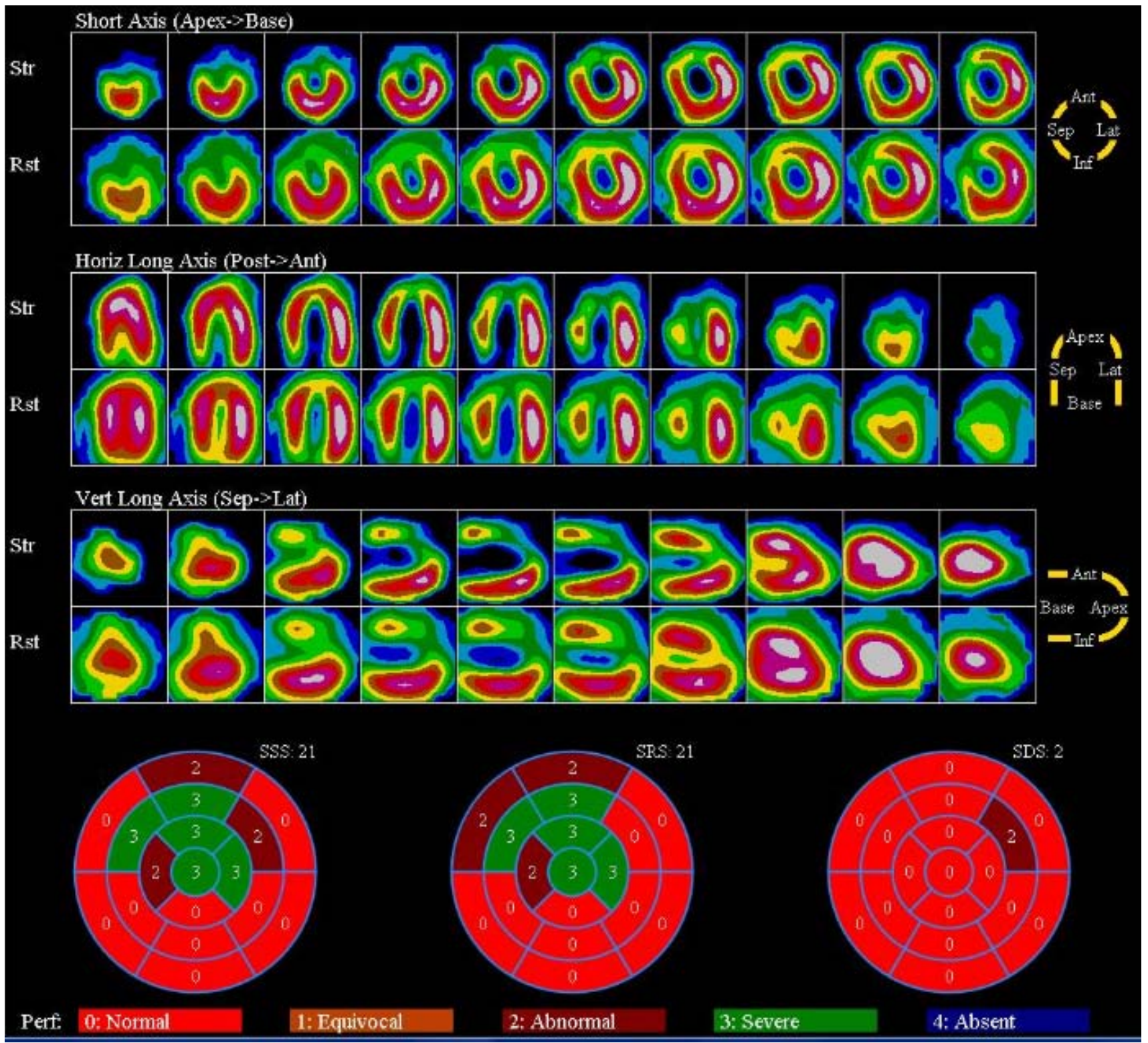

Figure 6. Single photon emission computer tomography (SPECT)

The typical presence of early systolic retrograde flow associated with no-reflow on intracoronary flow measurements was associated with the presence of microvascular obstruction assessed on LGE images..$^{21}$ Cardiac MRI features of reperfusion injury have been compared also with angiographic perfusion parameters like TIMI flow and myocardial blush grade (MBG). A study by Appelbaum et $\mathrm{al}^{22}$ in 21 patients who underwent successful primary PCI and MRI, evidence of impaired perfusion at first pass was present in $90 \%$ of cases with postPCI myocardial perfusion grade $(0 / 1 / 2)$, but only in $18.2 \%$ with normal one. Porto et $\mathrm{al}^{23}$ found a linear correlation in 27 patients with AMI between decreasing MBG and MRI signs of vascular obstruction.
Cardiac MRI features of no-reflow have prognostic significance in terms of clinical outcome and changes in LV volumes. ${ }^{14,24}$ The 'no-reflow phenomenon' refers to absent distal myocardial reperfusion after a prolonged period of ischaemia, despite the culprit coronary artery's successful recanalization, and likely secondary to both luminal obstruction and external compression by oedema and haemorrhage. ${ }^{25}$ The haemorrhagic AMI reflects the metamorphosis of ischaemic infarcts in the reperfusion era and are commonly observed after prolonged ischaemia once myocardial cell necrosis is well established. ${ }^{26}$ This phenomenon was also found in this patient since he came with 8 hours onset of AMI.

Microvascular cell damage causes leakage of blood out of the injured vessel and the subsequent healing 
process is characterized by haemoglobin degradation in which dark areas on post-contrast sequences indicate not only the presence of microvascular obstruction, but also of intramyocardial haemorrhage. ${ }^{27}$ The extent of the hemorrhagic area correlates with the size of 'dark zones' on LGE sequences. ${ }^{28,29}$ Patients with haemorrhagic AMI have shown a lower pre-PCI TIMI flow; moreover the area at risk, IS, and ratio of IS to area at risk were significantly larger. ${ }^{4}$ Furthermore, the size of 'dark zones' on post-contrast images is larger and interestingly present in all patients with haemorrhagic AMI. The hypoenhancement on T2-weighted images, suggesting intramyocardial haemorrhage (Figure 5 -right), is present in the majority of patients with dark zones on LGE (Figure 5-left) and also closely related to markers of IS and function. ${ }^{30}$ Though TIMI flow 3 was seen in this patient during coronary angiography, there was no prove that reperfusion injury had not happened yet until we performed cardiac MRI. So, we should be prepared for the outcome of these microvascular cell damages.

\section{Viability}

The major determinant of final transmural necrosis and microvascular damage is the duration of ischaemia, as demonstrated in vivo by MRI. ${ }^{31,32}$ The LGE represents a permanent memory of myocardial injury even after the acute phase of infarction..$^{33}$ IS on MRI appeared to diminish in size on follow-up. ${ }^{14,34}$ Baks et a ${ }^{35}$ evaluating the effects of primary PCI on early and late IS described a $31 \%$ decrease in LGE between 5 days and 5 months. Cardiac MRI in STEMI patients within 12 hours of primary PCI and at 6 months showed a reduction in LGE volume from 22 to $16 \%{ }^{36}$

IS within 1 week from AMI was directly related to LV remodelling and was a stronger predictor of future events than measures of LV systolic performance. ${ }^{36-38}$ The occurrence of LV dysfunction at 6 months increased with greater LGE: a cut-off of $\geq 23 \%$ LGE measured on hyperacute MRI showed the best accuracy for late LV dysfunction (sensitivity $89 \%$, specificity $74 \%$ ). ${ }^{36} \mathrm{In}$ the assessment of myocardial viability in AMI patients, when the extent of LGE is $<50 \%$ the likelihood for functional recovery is efficient. ${ }^{39}$ This patient had $34 \%$ LGE so we should manage the possibility of LV dysfunction in the near future and the extent of LGE was $>50 \%$, therefore the likelihood for functional recovery was decreased.

The main advantage of MRI LGE is its spatial resolution of 1-2 mm, contrary to about $10 \mathrm{~mm}$ with SPECT scans. ${ }^{40}$ Therefore, MRI can identify subendocardial necrosis when perfusion by SPECT appears unaltered. ${ }^{41,42}$ SPECT detection of LGEevidenced infarcts varied according to transmural extent: among segments with near transmural LGE (involving $>75 \%$ wall thickness) (Figure 4-right), all show evidence of infarct by SPECT, on the contrary segments with subendocardial LGE (involving < $50 \%$ wall thickness), SPECT detected infarct only in $53 \%$. Evaluating patients early after AMI, cardiac MRI was significantly more sensitive than SPECT for the detection of small infarcts and infarction in nonanterior region. ${ }^{42}$ SPECT showed the similar findings as MRI in this patient because the LGE in MRI was > $50 \%$ transmurality.

In conclusion, cardiac MRI can provide a wide range of clinically useful information in AMI by detecting not only location of transmural necrosis, infarct size, and myocardial oedema, but also showing in vivo important microvascular pathophysiological processes associated with AMI in the reperfusion era, such as intramyocardial haemorrhage and no-reflow. These impacts will help clinicians to manage and choose specific therapeutic strategies for AMI patients.

\section{REFERENCES}

1. Kuch B, Bolte HD, Hoermann A, et al. What is the real hospital mortality from acute myocardial infarction? Epidemiological vs clinical view. Eur Heart J. 2002;23:714-20.

2. Fox KA, Steg PG, Eagle KA, et al. Decline in rates of death and heart failure in acute coronary syndromes, 1999-2006. JAMA. 2007;297:1892-900.

3. Marra MP, Lima JAC, Iliceto S. MRI in acute myocardial infarction. Eur Heart J. 2011;32:284-93.

4. Ganame J, Messalli G, Dymarkowski S, et al. Impact of myocardial hemorrhage of left ventricular function and remodelling in patients with reperfused acute myocardial infarction. Eur Heart J. 2009;30:1440-9.

5. Flachskampf FA, Schmid M, Rost C, et al. Cardiac imaging after myocardial infarction. Eur Heart J. 2011;32:272-83.

6. Grotheus F, Moon JCC, Bellenger NG, et al. Interstudy reproducibility of right ventricular volumes, function and mass with cardiovascular magnetic resonance. Am Heart J. 2004;147:218-23.

7. Hundley WG, Bluemke DA, Finn JP, et al. ACCF/ACR/ AHA/NASCI/SCMR 2010 Expert consensus document on cardiovascular magnetic resonance: a report of the American College of Cardiology Foundation Task Force on Expert Consensus Documents. J Am Coll Cardiol. 2010;55;2614-62.

8. Plein S, Bloomer TN, Ridgway JP, et al. Steady-state free precession magnetic resonance imaging of the heart: comparison with segmented k-space gradient-echo imaging. J Magn Reson Imaging. 2001;14:230-6.

9. Pennel DJ. Cardiovascular magnetic resonance. Circulation. 2010;121:692-705.

10. Gotte MJ, Germans T, Russel IK, et al. Myocardial strain and torsion quantified by cardiovascular magnetic resonance tissue tagging: studies in normal and 
impaired left ventricular function. J Am Coll Cardiol. 2006;48:2002-11.

11. Aletras AH, Tilak GS, Natanzon A, et al. Retrospective determination of the area at risk for reperfused acute myocardial infarction with T2-weighted cardiac magnetic resonance imaging: histopathological and displacement encoding with stimulated echos (DENSE) functional validations. Circulation. 2006;113:1865-70.

12. Abdel-Aty H, Zagrosek A, Schulz-Menger J, et al. Delayed enhancement and T2-weighted cardiovascular magnetic resonance imaging differentiate acute from chronic myocardial infarction. Circulation. 2004;109:2411-6.

13. Friedrich MG, Abdel-Aty H, Taylor A, et al. The salvaged area at risk in reperfused acute myocardial infarction as visualized by cardiovascular magnetic resonance. J Am Coll Cardiol. 2008;51:1581-7.

14. Hombach V, Grebe O, Merkle N, et al. Sequelae of acute myocardial infarction regarding cardiac structure and function and their prognostic significance as assessed by magnetic resonance imaging. Eur Heart J. 2005;26:549-57.

15. Buja LM. Myocardial ischemia and reperfusion injury. Cardiovasc Pathol. 2005;14:170-5.

16. Phrommintikul A, Abdel-Aty H, Schulz-Menger J, et al. Acute oedema in the evaluation of microvascular reperfusion and myocardial salvage in reperfused myocardial infarction with cardiac magnetic resonance imaging. Eur J Radiol. 2010;74:12-7.

17. O'Regan DP, Ahmed R, Neuwirth C, et al. Cardiac MRI of myocardial salvage at the peri-infarct border zones after primary coronary intervention. Am J Physiol Heart Circ Physiol. 2009;297:340-6.

18. Englblom E, Hedstrom E, Heiberg E, et al. Rapid initial reduction of hyperenhanced myocardium after reperfused first myocardial infarction suggests recovery of the periinfarction zone: one-year follow-up by MRI. Circ Cardiovasc Imaging. 2009;2:47-55.

19. Carlsson M, Ubachs JF, Hedstrom E, et al. Myocardium at risk after acute infarction in humans on cardiac magnetic resonance: quantitative assessment during follow-up and validation with single-photon emission computed tomography. J Am Coll Cardiol Imaging. 2009;2:569-76.

20. Francone M, Bucciarelli-Ducci C, Carbon I, et al. Impact of primary coronary angioplasty delay on myocardial salvage, infarct size, and microvascular damage in patients with STsegment elevation myocardial infarction. J Am Coll Cardiol. 2009;54:2145-53.

21. Hirsch A, Nijveldt R, Haeck JDE, et al. Relation between the assessment of microvascular injury by cardiovascular magnetic resonance and coronary Doppler flow velocity measurements in patients with acute anterior wall myocardial infarction. J Am Coll Cardiol. 2008;51:2230-8.

22. Appelbaum E, Kirtane AJ, Clark A, et al. Association of TIMI myocardial perfusion grade and ST-segment resolution with cardiovascular magnetic resonance measures of microvascular obstruction and infarct size following ST-segment elevation myocardial infarction. J Thromb Thrombolysis. 2009;27:123-9.

23. Porto I, Burzotta F, Brancati M, et al. Relationship of myocardial blush grade to microvascular perfusion and myocardial infarct size after primary or rescue percutaneous coronary intervention. Am J Cardiol. 2007;99:1671-3.

24. Gerber BL, Rochitte CE, Melin JA, et al. Microvascular obstruction and left ventricular remodeling early after acute myocardial infarction. Circulation. 2000;101:2734-41.

25. Basso C, Thiene G. The pathophysiology of myocardial reperfusion: a pathologist's perspective. Heart. 2006;92:1559-62.

26. Basso C, Rizzo S, Thiene G. The metamorphosis of myocardial infarction following coronary recanalization. Cardiovasc Pathol. 2010;19:22-8.

27. Ewout J, Van Den Bos, Baks T, et al. Magnetic resonance imaging of hemorrhage within reperfused myocardial infarcts: possible interference with iron oxide-labelled cell tracking? Eur Heart J. 2006;27:1620-6.

28. Choi SH, Kang JW, Kim ST, et al. Investigation of T2weighted signal intesity of infarcted myocardium and its correlation with delayed enhancement magnetic resonance imaging in a porcine model with reperfused acute myocardial infarction. Int J Cardiovasc Imaging. 2009;1:247-56.

29. Stork A, Lund GK, Muellerleile K, et al. Characterization of the peri-infarction zone using T2-weighted MRI and delayed-enhancement MRI in patients with acute myocardial infarction. Eur Radiol. 2006;16:2350-7.

30. Beek AM, Nijveldt R, van Rossum AC. Intramyocardial hemorrhage and microvascular obstruction after primary percutaneous coronary intervention. Int $\mathrm{J}$ Cardiovasc Imaging. 2010;26:49-55.

31. Francone M, Bucciarelli-Ducci C, Carbon I, et al. Impact of primary coronary angioplasty delay on myocardial salvage, infarct size, and microvascular damage in patients with ST-segment elevation myocardial infarction. J Am Coll Cardiol. 2009;54:2145-53.

32. Tarantini G, Cacciavillani L, Corbetti F, et al. Duration of ischemia is a major determinant of transmurality and severe microvascular obstruction after primary angioplasty. A study performed with contrast-enhanced magnetic resonance. J Am Coll Cardiol. 2005;46:1229-35.

33. Rehwald W, Fieno DS, Chen EL, et al. Myocardial magnetic resonance imaging contrast agent concentration after reversible and irreversible ischemic injury. Circulation. 2002;105:224-9.

34. Ingkanisorn WP, Rhoads KL, Aletras AH, et al. Gadolinium delayed enhancement cardiovascular magnetic resonance correlates with clinical measures of myocardial infarction. J Am Coll Cardiol. 2004;43:2253-9.

35. Baks T, van Geuns RJ, Biagini E, et al. Effects of primary angioplasty for acute myocardial infarction on early and late infarct size and left ventricular wall characteristics. J Am Coll Cardiol. 2006;47:40-4.

36. Larose E, Rode's-Cabau J, Pibarot P, et al. Predicting late myocardial recovery and outcomes in the early hours of STsegment elevation myocardial infarction traditional measures compared with microvascular obstruction, salvaged myocardium, and necrosis characteristics by cardiovascular magnetic resonance. J Am Coll Cardiol. 2010;55:2459-69.

37. Eitel I, Desch S, Fuernau G, et al. Prognostic significance and determinants of myocardial salvage assessed by cardiovascular magnetic resonance in acute reperfused myocardial infarction. J Am Coll Cardiol. 2010;55:2470-9.

38. Wu E, Ortiz JT, Tejedor P, et al. Infarct size by contrast enhanced cardiac magnetic resonance is a stronger predictor of outcomes than left ventricular ejection fraction or endsystolic volume index: prospective cohort study. Heart. 2008;94:730-6.

39. Gerber BL, Garot J, Bluemke DA, et al. Accuracy of contrast-enhanced magnetic resonance imaging in predicting 
improvement of regional myocardial function in patients after acute myocardial infarction. Circulation. 2002;106:1083-9.

40. Wagner A, Mahroldt H, Holly TA, et al. Contrast-enhanced MRI and routine single photon emission computed tomography (SPECT) perfusion imaging for detection of subendocardial myocardial infarcts: an imaging study. Lancet. 2003;361:374-9.

41. Cury RC, Shash K, Nagurney JT, et al. Cardiac magnetic resonance with $\mathrm{T} 2$-weighted imaging improves detection of patients with acute coronary syndrome in the emergency department. Circulation. 2008;118:837-44.

42. Ibrahim T, Bulow HP, Hackl T, et al. Diagnostic value of contrast-enhanced magnetic resonance imaging and singlephoton emission computed tomography for detection of myocardial necrosis early after acute myocardial infarction. J Am Coll Cardiol. 2007;49:208-16. 